University of Nebraska - Lincoln

DigitalCommons@University of Nebraska - Lincoln

Faculty Publications, Department of Child, Youth, and Family Studies

Child, Youth, and Family Studies, Department of

2-2021

Best Practices for Preschool Music Education: Supporting

Music-Making Throughout the Day

Jentry Stoneman Barrett

Rachel E. Schachter

Danni Gilbert

Mathew Fuerst

Follow this and additional works at: https://digitalcommons.unl.edu/famconfacpub

Part of the Developmental Psychology Commons, Early Childhood Education Commons, Family, Life Course, and Society Commons, Music Education Commons, Other Psychology Commons, and the Other Sociology Commons

This Article is brought to you for free and open access by the Child, Youth, and Family Studies, Department of at DigitalCommons@University of Nebraska - Lincoln. It has been accepted for inclusion in Faculty Publications, Department of Child, Youth, and Family Studies by an authorized administrator of DigitalCommons@University of Nebraska - Lincoln. 


\title{
Best Practices for Preschool Music Education: Supporting Music-Making Throughout the Day
}

\author{
Jentry S. Barrett, ${ }^{1}$ Rachel E. Schachter, ${ }^{1}$ \\ Danni Gilbert, ${ }^{2}$ and Mathew Fuerst ${ }^{3}$ \\ 1 Department of Child, Youth and Family Studies, University of Nebraska-Lincoln \\ 2 Glenn Korff School of Music, University of Nebraska-Lincoln \\ 3 Music Department, Doane University \\ Correspondence — Jentry S. Barrett, jbarrett3@unl.edu
}

\begin{abstract}
Active engagement in music has numerous academic and social benefits for young children and music-making is included in many early childhood standards and preschool curricula. The purpose of this article is to provide quality resources for classroom teachers to use in providing music-making activities for young children, ages 3-5. Although teachers may use music in their classrooms, we provide resources and suggestions for more intentional and extended integration of music-making. Specifically, we identify best practices for preschool music education based on key standards and research as well as with common music pedagogies. We then turn to concrete examples of how teachers can implement these music best practices throughout the entire preschool day. We provide ideas and resources for wholegroup activities, focusing on choice-time/center activities and ways to incorporate
\end{abstract}

Published in Early Childhood Education Journal, 2021

doi:10.1007/s10643-021-01155-8

Copyright (c) Jentry S. Barrett, Rachel E. Schachter, Danni Gilbert, and Mathew Fuerst, under exclusive license to Springer Nature B.V. part of Springer Nature 2021. Used by permission.

Accepted 7 January 2021; published 17 February 2021.

Suggested citation: Barrett, J.S., Schachter, R.E., Gilbert, D. et al. Best Practices for Preschool Music Education: Supporting Music-Making Throughout the Day. Early Childhood Educ J (2021). https://doi.org/10.1007/s10643-021-01155-8 
music activities in other academic areas as these seem to be of greater need for teachers. Finally, we use the stated best practices to review the alignment of a sample of commercially available preschool music curricula as an additional support for teachers.

Keywords: Preschool, Music-making, Curricula, Developmentally appropriate practice

Planned, teacher-directed music instruction in classrooms serving preschool (3-5-year-old) children has been shown to improve children's language and literacy outcomes (Bolduc et al. 2020; Degé and Schwarzer 2011; Hallam 2010; Jordan-DeCarbo and Galliford 2011; Lorenzo et al. 2014; Runfola et al. 2012), pro-social behavior (Brown et al. 2017; Ilari 2016; Kirschner and Tomasello 2009; Trainor and Cirelli 2015), and gross motor development (Deli et al. 2006; Derri et al. 2001). As such, many early childhood organizations support the inclusion of music education in the classroom (e.g., National Association for the Education of Young Children [NAEYC] 2017; National Association for Music Education [NAfME] 2014; International Society for Music Education [ISME] 2016) and music-making is a component of many early learning standards (e.g., Early Years Foundation Stage Statutory Framework in England 2017; Ministry of Education, Culture, Sports, Science and Technology in Japan 2008; National Curricular Common Base in Brazil 2017; The South African National Curriculum Framework for children from Birth to Four 2015; Nebraska State Early Learning Guidelines 2018) and curricula (e.g., Creative Curriculum, Dodge and Teaching Strategies 2011; HighScope, Educational Research Foundation 2012). Thus, there is an expectation that early childhood teachers will be designing and implementing music in the classroom.

However, given the competing demands on early childhood teachers' instructional time, as well as the focus on holistic and emergent curricula (Jones 2012; Kostelnik et al. 2019; NAEYC 2009), implementing multiple and varied music activities across the day may be a challenge for teachers. For example, Gillespie and Glider (2010) found that music typically was used in classrooms during large group (e.g., circle time) or to facilitate transitions (e.g., cleaning up) but less so during play or child-directed time, other than as background music. However, these child-directed play times are considered a hallmark of early childhood education (Golinkoff et al. 2006; Nicolopoulou 
2010; Wood 2004) and constitute a large portion of learning time in early childhood (Early et al. 2010; Fuligni et al. 2012); thus, presenting a missed opportunity for supporting children's development. Most of what we know about music-making in EC classrooms comes from teacher reports, and even that is limited (Ehrlin and Tivenius 2018; Lee 2009; Nardo et al. 2006; Rajan 2017). These surveys find that teachers would like more resources to teach music, including training, ideas for lessons, and instruments. ${ }^{1}$ This need for support may be particularly pressing as most music education in early childhood settings is provided by the classroom teachers (Bolduc and Evard 2017; Nardo et al. 2006) who may not have extensive music (or even creative arts) preparation (Barrett 2014; Kretchmer 2002; Lee 2009; Lenzo 2014), in contrast to a music specialist whose entire training is focused on musical pedagogy (May et al. 2017). Indeed, although there is a well-established base of music methodology developed by pedagogues such as Orff, Kodály, and Dalcroze that is typically incorporated into music specialist training, it is unlikely that typical early childhood classroom teachers would have exposure to training regarding these pedagogies.

Researchers have argued that early childhood teachers are unfamiliar with pre-K music standards (Kirsten 2006; Rajan 2017). Thus, identifying how the standards and developmentally appropriate practice align, could provide teachers more musical self-efficacy which could lead to more musical opportunities for preschool children (Bolduc and Evrard 2017; Lenzo 2014). The purpose of this article is to support preschool teachers by providing musical content knowledge, ideas for the classroom, and a review of commercially available curricula. Specifically, we identify best practices for preschool music education based on key standards, research, and common music pedagogies such that music time can enhance children's musical abilities in addition to children's enjoyment. We then turn to concrete examples of how teachers can implement these music best practices throughout

1. What is even less researched is preschool children's preferences regarding music-making in the classroom (Marsh and Young 2006; Young and Illari 2018). Although the scope of this manuscript focuses on providing quality resources for classroom teachers to use for music-making activities for young children, ages $3-5$, it is important to note that adding children's experiences and preferences would enhance the ability to support high-quality music-making activities. 
the entire preschool day. Although we provide ideas and resources for whole-group activities, we also focus on choice-time/center activities and ways to incorporate music activities in other academic areas, as these seem to be of greater need for teachers (Gillespie and Glider 2010). Finally, we summarize the alignment of common commercially available music curricula with the best practices as an additional resource for teachers.

\section{What is Best Practice for Preschool Music Education?}

In order to identify best practices in music education, we reviewed multiple publications of state and national preschool standards, learning guidelines, curricula, and music textbooks on early childhood education to synthesize recommendations and clarify expectations as to what constitutes high-quality, age-appropriate music-making in preschool (listed in Table 1). Specifically, these documents included: (1) textbooks and relevant texts used in syllabi from early childhood music pre-service classes taught throughout the BIG 10 Universities (btaa.org) in the United States; (2) accreditation standards and guidelines from the United States and local preschool organizations including NAEYC (2017), Head Start Domains (2010), and Nebraska's Early Learning Guidelines 3-5 (2018); (3) learning guidelines from the two most commonly used preschool curricula: Creative Curriculum and HighScope (Schachter et al. 2020; Cross and Conn-Powers 2014); and (4) the NAfME standards for music educators teaching preschool through twelfth grade published in 2014. We conducted a conventional content analysis of these texts (Hsieh and Shannon 2005) to identify best practices for music education with 3- to 5-year-old preschool children. This allowed coding categories to emerge from the data, and the key concepts were then combined and summarized into nine best practices (BP) as shown in Table 1, which also displays which data sources support the best practices. Additionally, given that there are many common approaches to music pedagogy (e.g., Dalcroze, Orff, and Kodály), we incorporate these ideas to help elaborate and explain the best practices. 


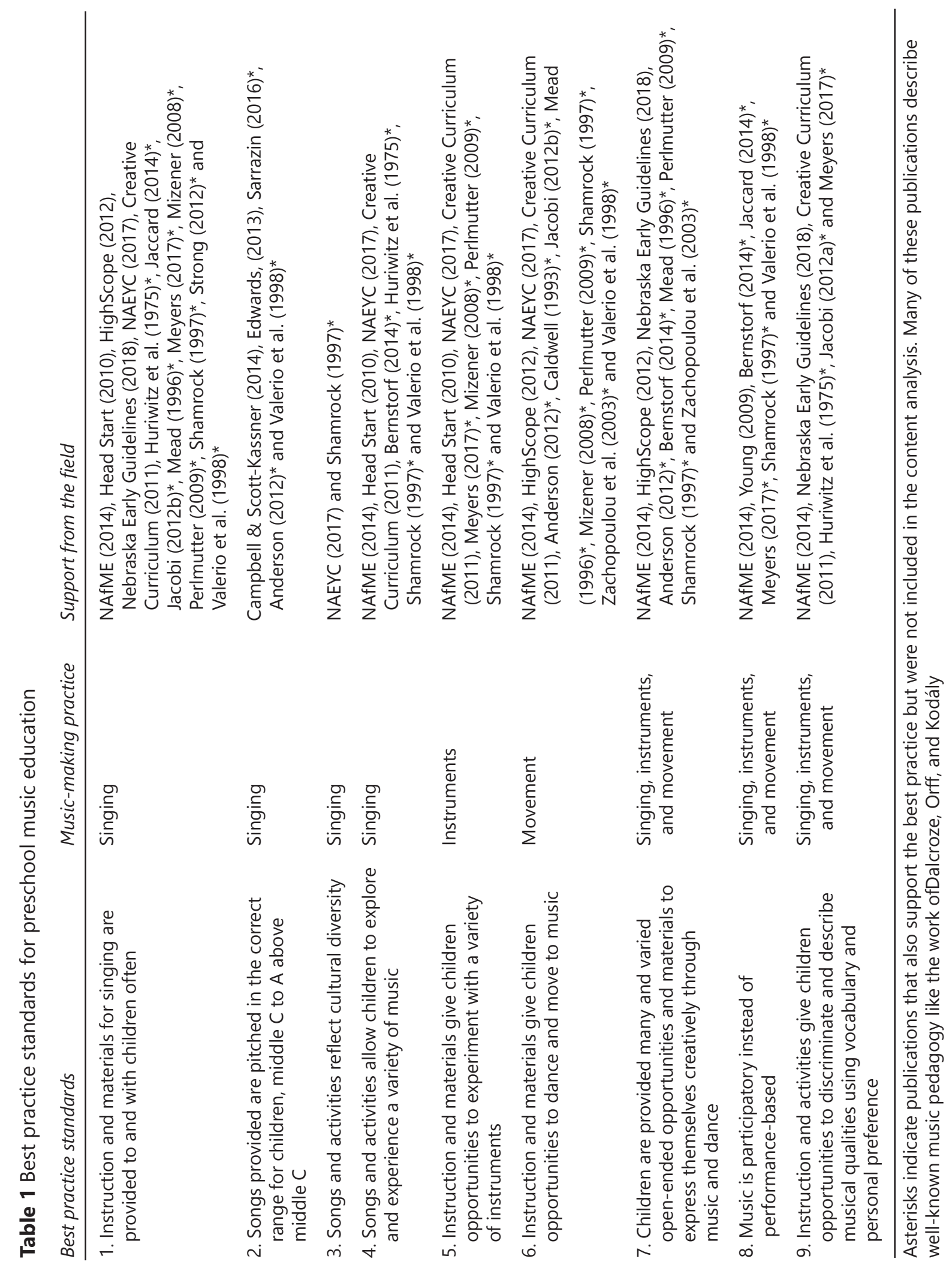


The nine identified best practices (BP, shown in Table 1) provide a guide for implementing high-quality music instruction in preschool classrooms. Across these nine best practices, three distinct categories of music-making practices emerged-singing, using instruments, and movement (see Table 1). This grouping of practices is supported by the Orff and Kodály pedagogies. For example, the Orff approach links music and movement through singing, clapping, and dancing activities that perhaps come naturally to children (Perlmutter 2009). The Kodály system is comprised of a sequential curriculum geared for young children that uses techniques such as signs, games, clapping, rhythmic notation, and singing to teach folk songs (Huriwitz et al. 1975). We hope to utilize the results of the content analysis with support from the common music education pedagogies to give teachers a valuable music-making instructional guide. Next, we will define and elaborate each best practice by describing what age-appropriate music-making looks like and by providing examples of age-appropriate expectations for music-making.

\section{Singing}

Many of the best practices identified involve singing or the use of songs (BP 1-4, 7-9). The songs and games children learn in preschool become material that can be used to assist with learning to read and write once they enter grade school (Jacobi 2012b). Musical development through chanting and rhythmic speaking, singing, and listening can strengthen language development (Mizener 2008). Continually singing songs is important because children need many repetitions through a song before they can easily reproduce all parts (Suthers and Niland 2007). As children learn songs, they can reproduce the words of the song first, then the rhythm of the song, and finally the pitches in the song (Hargreaves and Zimmerman 1992). Repetition of songs also increases preference for those songs (Merrion 1989). Children's musical development is similar to development across other domains, namely, skills develop over time with certain skills developing first and becoming familiar and easy for children before additional skills can be introduced or mastered (Kostelnik et al. 2019). The next sections will describe typical sequences of musical skills for preschool children. 
As with all skills, there is a developmental continuum in learning to sing or engaging with songs. For example, 3-year-old children enjoy singing familiar songs in groups like nursery rhymes and childhood chants, but rarely match pitch as a group (Campbell and Scott-Kassner 2014; Edwards 2013; Michè 2002; Pica 2012). As children's language acquisition grows, their music learning grows at the same intensity (Brandt et al. 2012). Four-year-old children may start to discover the difference between their speaking and singing voices and may be able to sing spontaneous songs spanning two octaves. However, they may only sing in tune within a range of six pitches, middle $C$ to $A$ above middle C (Anderson and Lawrence 2013; Campbell and Scott-Greata 2006; Kassner 2014; Sarrazin 2016). Figure 1 depicts the range in which children can sing and the smaller set of notes in which they can stay in tune. Teachers can ensure that vocal cords can continue healthy development by selecting songs where the majority of the notes are in this six-note range. Figure 2 depicts several common preschool songs and their general alignment with this range. Children's limited range is accommodated in the Dalcroze approach to music education, by beginning children's singing instruction using the note middle $C$ (Anderson 2012). Four-year-old children still like repetitious music, but start to enjoy more intricate music, humorous lyrics, and making up personal lyrics to familiar melodies (Edwards 2013; Michè 2002; Pica 2012). These children can also grasp basic musical concepts, such as tempo, volume, and pitch (Pica 2012).

Finally, 5-year-old children can sing songs with a wider range of pitches and can sing entire repetitive songs independently and with a group (Creative Curriculum 2011; Gooding and Standley 2011). These children begin to conceptualize aspects of pitch and melody like low and high and have an emerging sensitivity to intervals, tonality, and can identify specific instruments (Campbell and Scott-Kassner 2014; Edwards 2013). They can also say what a piece of music suggests to

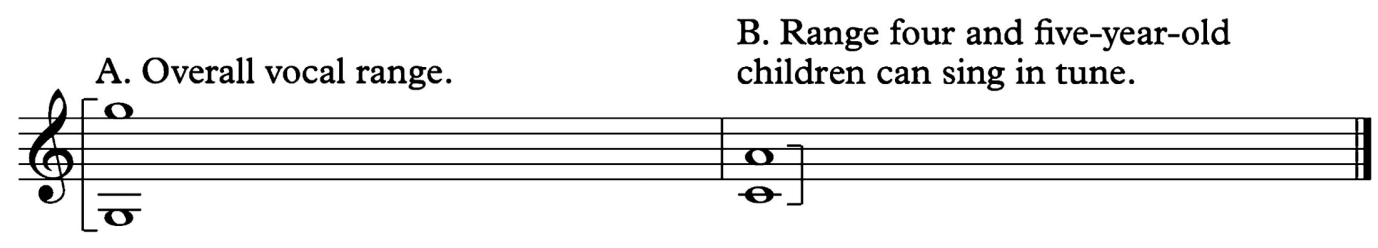

Fig. 1 Typical range of 4 - and 5-year-old children 



Like a dia-mond in the sky. Twin-kle, twin-kle lit-tle star, how I won-der what you are.

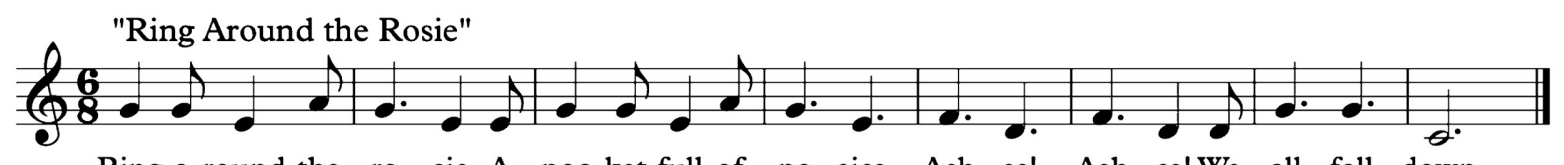

Ring a-round the ro-sie, A poc-ket full of po-sies, Ash-es! Ash-es! We all fall down.
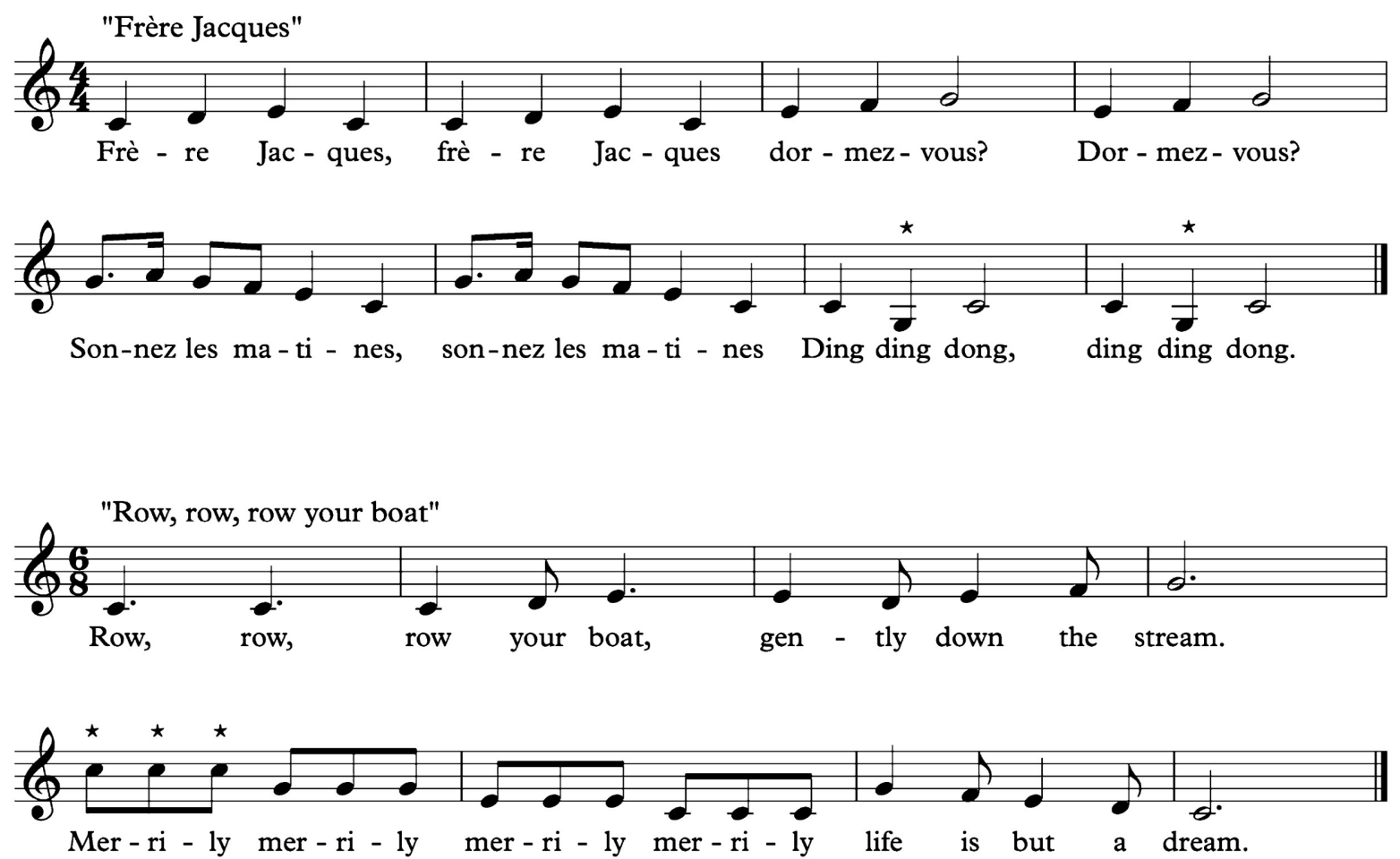

Fig. 2 Examples of songs that generally fit within children's in-tune range. The stars indicate notes that children typically cannot sing in-tune 
them-does it sound happy, sad, like running water, or a quiet forest? Five-year-old children are also becoming active listeners, meaning that with guidance from the teacher, they can learn to identify instruments, melody, phrases, and rhythmic elements when listening to music (Edwards 2013).

\section{Instruments}

Interacting with instruments is also an important component of the best-practices (BP $5 ; 7-9$ ). Before simple rhythm instruments are introduced, teachers can use body percussion like clapping, patting body parts, and stomping on the ground (Brewer 2001; Campbell and Scott-Kassner 2014; Edwards 2013). Using body percussion to accompany rhythmic chants and sound patterns scaffolds the learning before rhythmic instruments are used and is standard practice in the Orff approach (Mizener 2008). Body percussion helps with gross motor skills, aids in the transition to instruments, and is budget friendly. Once body percussion has been explored and is easy for the children to incorporate, teachers can include simple rhythm instruments like rhythm sticks, jingle bells, and egg shakers during large-group music instruction. A variety of instruments with which children explore and create can also be part of a classroom music center (BP 7). Instruments are an easy way to encourage participation in music-making (BP 5), especially if a child is reluctant to sing.

Three-year-old children are not able to keep a steady beat for very long but can play and silence a hand instrument at will. Recommended instruments for this age would include rattles, jingle bells, hand drums, or rhythm sticks, played mostly by striking or shaking the instrument (Campbell and Scott-Kassner 2014). Four-year-old children experience greater ease at creating and maintaining a steady beat and are also able to sway to a pulse with their arms. Additional instruments to try with this age group could include claves, woodblocks, sand blocks, maracas, or a cowbell. Four-year-old children are also able to use instruments in alternative ways. They can rub rhythm sticks, woodblocks, or sand blocks together instead of only striking them. Finally, 5 -year-old children can maintain a steady beat, can alternate their hands when striking a drum, and have more eye-hand coordination. This improved coordination allows them to strike a drum at the visual 
cue of the teacher and to use more intricate instruments like a triangle or finger cymbals. If children are ready for even more complex instruments, the Orff approach typically uses melodic percussion equipment such as glockenspiels, xylophones, and bass bars (Perlmutter 2009). These melodic percussion instruments would be an excellent addition to a music choice-time/center activity.

\section{Movement}

Movement is another key component of high-quality musicmaking (BP 6-9). The relationship between music and movement, or eurhythmics, forms the core of the Dalcroze approach to music education (Anderson 2012). Eurhythmics is the idea that the source of rhythm is found in the body and that children can organize rhythmic stimuli and translate them into existing movement patterns such as walking, skipping, and running (Zachopoulou et al. 2003). Dalcroze thought that all musical concepts could —and should — be taught through movement (Caldwell 1993). When dancing, children learn to discriminate between fast and slow (tempo), and different musical moods. Children also learn flexibility, coordination, timing, and anticipation (Young 2009). Thus, moving to music can have a substantial effect on preschool children's physical coordination or motor development, an important early childhood outcome (Derri et al. 2001; Kostelnik et al. 2019).

Just like singing, children's ability to move to music is age and experientially driven. Three and four-year-old children can walk, run, dance, and jump to music but can only march or clap to a beat with some accuracy (Edwards 2013; Michè 2002; Pica 2012). Children's development happens head down and middle out, so children will be able to coordinate their hands before they can coordinate their feet (Hooper and Umansky 2013). Because of this coordination lag in three and 4-year-old's feet, unstructured free dancing-dancing without the constraints of moving to a beat or choreography (Greata 2006)is appropriate for this age group. While dancing, children develop an awareness of how they move in space and how others are moving, stopping, and balancing their bodies (Young 2009). Five-year-old children are developing patting, galloping, jumping rope, and rhythmic clapping. They can tap in time to a regular pulse and perform simple dances in circles and lines (Campbell and Scott- Kassner 2014; 
Edwards 2013). Five-year-old children can also participate in synchronized movement, moving with the beat of the music, or with peers in simple circle or line dances, although they still enjoy free dancing (Greata 2006).

\section{Suggestions for Implementing Music-Making Activities}

Next, we provide suggestions on how to structure whole-group music lessons and describe how to create an engaging music choice-time/ center activity. Finally, we provide suggestions for incorporating music into other academic domains/contents.

\section{Whole-Group Music Lessons}

First, we suggest incorporating music-making time every day, as part of a predictable daily routine, if it is not already. Many teachers may be singing a welcome song during circle time, or playing music during clean-up time, but we suggest having a lesson plan that includes intentional singing, movement, and instruments each day, as well as variation across the year to increase children's musical abilities. The same activities can be repeated across the week and maybe even over the entire month. Remember that learning new songs for children takes time and many coordinated skills; thus, learning or singing different songs every day does not allow children the time they need to succeed. Feierabend (2004) suggests repeating each rhyme or song at least four instances during the music lesson, and not retiring the song/ rhyme until the children have performed it at least 16 times over the week or month. Teachers can choose four to five songs and activities for the week and introduce only one new activity each day, and then repeat songs or activities learned in previous lessons with added extensions. Extensions can include incorporating different movements, adding or changing instruments, or finding a game that corresponds with the song or activity. Table 2 includes a variety of online resources to support planning and implementing music-making activities.

There are also low-cost online resources for teachers to use in creating music-making curricula. One is the University of Nebraska-Lincoln's Early Childhood Professional Development online lesson, Sing 
Table 2 Music resources for preschool teachers

\begin{tabular}{|c|c|c|}
\hline Title & Description & Website \\
\hline \multicolumn{3}{|l|}{ Resources for content knowledge } \\
\hline Alliance for Active Music Making & Descriptions of music learning & https://www.allianceamm.org/ \\
\hline $\begin{array}{l}\text { Early Childhood Music and } \\
\text { Movement Association }\end{array}$ & Connect with other preschool teachers & http://www.ecmma.org/ \\
\hline $\begin{array}{l}\text { Feierabend Association for } \\
\text { Music Education }\end{array}$ & Information and resources & https://www.feierabendmusic.org/ \\
\hline $\begin{array}{l}\text { Gordon Institute for Music } \\
\text { Learning }\end{array}$ & Music Learning Theory Information & https://www.giml.org \\
\hline $\begin{array}{l}\text { Montessori World Educational } \\
\text { Institute }\end{array}$ & How to help children sing in class & https://bit.ly/2XwD5hN \\
\hline NAEYC Music and Song Page & Music resources from NAEYC & $\underline{\text { https://bit.ly/2ly } 1 Y X d}$ \\
\hline \multicolumn{3}{|c|}{ Resources for lesson plans and songs } \\
\hline Beth's Notes & Songs and lesson plans & https://www.bethsnotesplus.com \\
\hline Experience the Music & Literacy-based music curriculum & https://experiencethemusic.org \\
\hline $\begin{array}{l}\text { Kodály Center: The American } \\
\text { Folk Song Collection }\end{array}$ & Collection of songs and games & http://kodaly.hnu.edu/collection.cfm \\
\hline Let's Play Music & Website with lesson plans & https://letsplaykidsmusic.com \\
\hline $\begin{array}{l}\text { Montessori World Educational } \\
\text { Institute }\end{array}$ & Songs in developmental order & https://bit.ly/2ly $1 \mathrm{dNR}$ \\
\hline $\begin{array}{l}\text { Music Play II: The early child- } \\
\text { hood music curriculum guide }\end{array}$ & $\begin{array}{l}\text { Music curriculum taught } \\
\text { by a music specialist }\end{array}$ & https://bit.ly/390Vdb9 \\
\hline PreKinders & Free music resources and ideas & https://prekinders.com/category/music/ \\
\hline Sing and Play with Me! & Module for preschool music & https://go.unl.edu/p0md \\
\hline Teaching 2 and 3 -year-olds & Activities and lesson plans & $\begin{array}{l}\text { https://teaching2and3yearolds.com/music- } \\
\text { and-movement-activities-for-toddlers-and- } \\
\text { preschoolers }\end{array}$ \\
\hline \multicolumn{3}{|l|}{ Resources for purchasing materials } \\
\hline Music \& Arts & Purchase classroom instruments & www.musicarts.com \\
\hline Music in Motion & Purchase classroom instruments & www.musicinmotion.com \\
\hline Woodwind Brasswind & Purchase classroom instruments & www.wwbw.com \\
\hline
\end{tabular}

and Play with Me! (Barrett 2017; https://go.unl.edu/p0md). Another is the website, Beth's Notes (https://www.bethsnotesplus.com), where developmentally appropriate songs and lesson plans are provided for free, and a library of songs and resources are behind a paywall. Holy Names University also has an extensive online library of children's songs and games with filters to choose the most appropriate for a teacher's class (http://kodaly.hnu.edu/). Other internet resources can be found in Table 2, including websites for purchasing classroom instruments. Importantly, simply playing music videos for children is not enough to meet music-making best practices. Teachers should purposively plan for how to use online resources within the context of interactive activities. 
Remember to consider children's interests in musicmaking activities. This can include selecting songs that they enjoy or planning music experiences that tie into other classroom activities or interests from the environment. For example, teachers could incorporate singing about cars, trucks, airplanes, and trains during a transportation unit, or singing about sun, rain, wind, and snow during a weather unit. Also, teachers can ask for children's input into how they will perform activities. One way to do this is to ask each child in the circle how they would like the class to tap their rhythm sticks during one repetition of the song. One child might want to tap them together while the next child might choose to tap them on the floor. This way, everyone gets a turn to express their preferences (BP 9), and the song is sung multiple times, supporting children's learning. Other opportunities for involving child choice during a music lesson also could include asking how to dance to the music (such as to Rameau's Abaris ou les Boréades) or which direction the circle should walk during Ring around the Rosy. Finally, for older children, they can take turns leading the predictable parts of the music activities (e.g., handing out instruments, leading songs, etc.). Table 3 provides a sample of what kinds of activities could be part of a music lesson. It also provides ideas on how music activities support other learning domains (Head Start Domains 2010).

\section{Music Choice-Time/Center Activities}

Creating a music choice-time/center activity is another way to incorporate music into the classroom and move beyond traditional large group music-making lessons. These centers can include small musical instruments like; drums, jingle bells, and glockenspiels, scarves with which to dance, a listening station with a music player and headphones, and books about musical instruments and musicians. The selections on the music player can be a great way to introduce children to music from other cultures and time periods. The listening station can include a CD player where the children choose the CD they want to hear, an mp3 player where the teacher creates playlists, or a tablet or other device with videos of symphony orchestras or children's music. How to engage with the resources can be modeled for children by teachers and then left for children to explore independently, with peers, or supported by an adult. Finally, another addition could be 


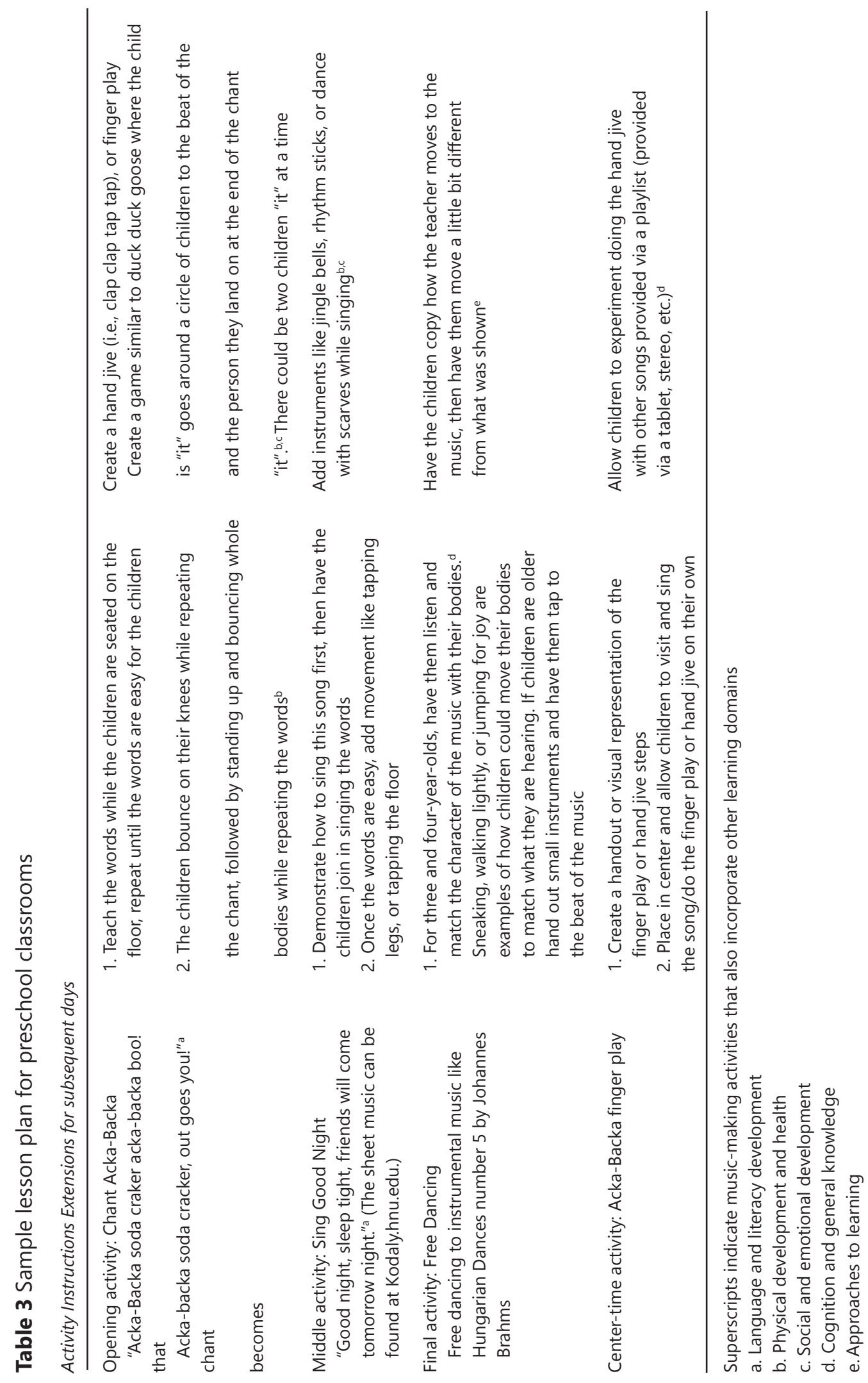


storybook versions of popular songs (e.g., Baby Beluga Raffi 1997; Old MacDonald Had a Farm, Adams 2000; The Itsy-Bitsy Spider, Crow 2017) for children to access.

The music choice-time/center activity is an ideal place for teachers to have one-on-one interactions with a child or children using musical instruments. A game that Young (2009) encourages is "my turn, your turn" during choice-time/center activities. Both the child and the teacher have the same instrument, and the teacher plays a short three or four-beat pattern (i.e., four steady hits on a drum). When the child repeats the pattern, the teacher can praise the child and repeat the game. After the child finds it easy, the teacher then offers to repeat a pattern that the child creates. Playing this game shows the child that the teacher is present because they are repeating back what the child is producing, and the teacher is extending the learning by having the child create patterns. Having the child repeat back the teacher's pattern, only slightly different (i.e., changing from fast to slow hits, or from loud to soft) could be another extension after a few rounds of the easier version. This type of 'serve and return' teacher-child interaction can hone listening and musical skills and can introduce children to contrasts in sounds, tempos, dynamics, and moods (BP 9). Serve and return interactions are also essential for wiring children's brains for language development (Center on the Development Child 2016), and music can be another way teachers create serve and return opportunities (Reynolds and Burton 2017).

\section{Using Music-Making to Support Other Learning Domains}

In addition to designated music-specific activities such as large group and choice-time/center activities, music-making can be integrated into other academic domains across the curriculum. This fits naturally with other efforts to provide holistic, emergent, early childhood curricula that integrate multiple content areas into activities (e.g., providing writing materials in the block area, integrating a cash register into dramatic play; Jones 2012; Jones and Nimmo 1994; Kostelnik et al. 2019; NAEYC 2009). Specifically, there are many opportunities to integrate music-making best practices into classroom activities.

In some ways, singing may be the most intuitive to integrate (BP $1-4,7-9)$. For example, singing songs provide myriad opportunities 
to introduce content and ideas from other domains. Further, once children have learned the song, the addition of instruments and movement (BP 5-9) are easy extensions to learning and enjoyment. Common songs such as Head, Shoulders, Knees, and Toes or the Hokey Pokey provide opportunities to learn about body parts addressing learning domains related to health and science. Movement in these songs is a given, and handheld rhythm instruments can be added to create new ways to sing the song ("put the bells in, put the bells out"). This extension of the activity allows for inhibitory control practice if only a subset of the children have bells in their hands and the children with rhythm sticks must wait their turn while their classmates participate, furthering the development of social and emotional skills (Ladd et al. 1999). Other songs from the Western Folk Song tradition can help with listening and following directions or steps (e.g., Freeze Dance, If You're Happy and You Know It, Teddy Bear Teddy Bear, I'm a Little Teapot, The Wheels on the Bus) addressing cognitive developmental domains. Again, movement is inherent to these songs already, and simple rhythm instruments would be an easy extension during subsequent lessons.

Additionally, as described previously, there is a link between music and early language and literacy skills (Jacobi 2012b; Jordan-DeCarbo and Galliford 2011; Lorenzo et al. 2014; Mizener 2008; Runfola et al. 2012). Singing provides an opportunity for developing phonological awareness - the ability to hear, differentiate, and manipulate sounds in speech (Lonigan and Shanahan 2008). This can include hearing the differing phonemes or sounds in words, particularly through the high prevalence of rhyming (similar ending sounds) in songs. Whereas singing provides an opportunity for children to manipulate sounds in speech, moving to music and using instruments while reading affords children practice manipulating their bodies and honing their self-regulation (Derri et al. 2001; Winsler et al. 2011) while learning about cadence and prosody during reading (Lonigan and Shanahan 2008). This not only supports language and literacy development but can encourage independence and curiosity about reading (approaches to learning). Finally, programmatic studies that combine stories with music are also a great way to integrate music-making activities and can support language and cognitive development. For example, classrooms could read various versions of Cinderella, compare how 
different authors present the story, and then listen to the music by Prokofiev or Rogers and Hammerstein (BP 9). There are also musical works for Peter and the Wolf, Where the Wild Things Are (Sendack and Schickele 1963) and Hansel and Gretel, to name a few.

Music-making can be integrated into cognitive domains through activities that connect with children's environments, such as having children and families share songs and dances from their home culture (social and emotional development, BP 9). Instruments can also be used to replicate sounds heard in nature-such as tapping to emulate rain or even blowing through an open paper towel tube to replicate wind (BP 5). Music like the Four Seasons by Vivaldi can be presented to help children think about musical representations of the weather and other elements. Similarly, Carnival of the Animals by Saint-Saens includes animal and aquarium sounds, the overture to William Tell by Rossini depicts thunderstorms and horse galloping, Flight of the Bumblebee by Rimsky-Korsakov can imitate bees, and Symphony No. 6 (Pastoral) by Beethoven has nightingale and cuckoo calls as well as thunderstorms. Finally, music, instruments, and movement can be used to convey moods and feelings. For example, when children are feeling strong emotions, intense music-like Elgar's Cello Concerto in E minor-might help them embrace those feelings and express their emotions (BP 7). Children can learn to create music that matches what they are feeling inside. Similarly, teachers can play music and have children give their suggestions of feelings created for them by the music (BP 9).

\section{Curricula Resources}

If time or resources do not allow for a teacher-created music curriculum, a commercially available music curriculum can be valuable support. However, very little research exists regarding whether music curricula content adheres to the best practices previously identified. This is problematic because, without this information, music curricula implementation decisions could be under-informed. To guide preschool teachers, administrators, or programs regarding which available preschool music curricula embody musicmaking best practices, we reviewed a sample of popular, English-language, preschool music curricula for their alignment to the nine best practices. 
The curricula reviewed were: Do Re Me and Maria: World Music and Rhythm Talk, Kindermusik@School: Laugh \& Learn, The Musical Child: Sing and Play 1, Preschool Prodigies: PSP Playground, and The Tuneables: I Love Music. We contacted publishers, and they provided sample curricula, audio, and information about their products. ${ }^{2}$ Each of these curricula were then reviewed against the best practices for preschool music education in Table 1. Table 4 provides a summary of how the curricula align with the nine best practices. Notably, although these curricula included many best practices, Kindermusik incorporated the most.

In general, most curricula fit many of the best practices including singing and moving to music. We caution that across these curricula often songs are pitched too low for young voices or are sung by a male vocalist that sings an octave below where the children are meant to sing. Children often find it difficult to sing an octave above what they hear until the fourth grade (Campbell and Scott-Kassner 2014). Also, teachers should be wary of curricula that do not offer cultural diversity in songs and activities, or curricula that do not encourage individual musical expression. For more detailed information on the curricula analysis, please see the online appendix.

For teachers or programs who choose to use a curriculum, we suggest using the curriculum to support music instruction, with a gradual movement to independence as the teacher becomes more comfortable teaching music. Curriculum materials can be used as a jumping-off point for exploration, and teachers can create extensions that connect with the other learning taking place in the classroom. Importantly, the five curricula we reviewed vary greatly in the amount of discretion given to teachers to take the lessons in a new direction. Regardless of curriculum use, we encourage teachers to find other times during the day to use the songs, rhymes, dances, or instruments to make connections across their curriculum.

2 We do not consider this a comprehensive list of preschool music curricula; some publishers and authors were unresponsive or unwilling to provide a sample of the curricula for review. We also chose not to include curricula that were mostly geared for music specialists. We have listed some of these music specialist curricula in Table 2 because they are high-quality and can provide preschool teachers with valuable information. 







\section{Conclusion}

We encourage teachers to include music as part of the preschool day as it is part of the standards and guidelines set forth by governments, accreditation organizations, and preschool curricula. Music is enjoyable for both children and teachers and holds such potential for creating connections between the teachers and children while providing opportunities for learning and discovery and enhancing academic (Lorenzo et al. 2014), and social skills (Kirschner and Tomasello 2009; Trainor and Cirelli 2015). With strategic planning, teachers, directors, and programs can use the best practices for music-making to support music an integral part of the preschool classroom and children's learning experiences.

Supplementary material is available following the References.

\section{References}

Adams, A. (2000). Old MacDonald had a farm (classic books). Swindon: Child's Play International.

Anderson, W. T. (2012). The Dalcroze approach to music education: Theory and applications. General Music Today, 26(1), 27-33. https://doi. org/10.1177/1048371311428979

Anderson, W. M., \& Lawrence, J. E. (2013). Integrating music into the elementary classroom (9th ed.). Cengage Learning.

Barrett, J. S. (2014). Making music time easier to teach in early childhood classrooms [Unpublished master's thesis]. University of Nebraska-Lincoln.

Barrett, J. S. (2017). Sing and play with me: Music for the young child. Retrieved February 2021, from https://childpd.unl.edu/index.php?menu=sing with me

Bernstorf, E. (2014). Oh, how lovely: Rounding up support for Kodály-inspired instruction. Kodaly Envoy, 41(1), 17-19.

Bolduc, J., \& Evrard, M. (2017). Music education from birth to five: An examination of early childhood educators' music teaching practices. Research and Issues in Music Education, 13(1), 3.

Bolduc, J., Gosselin, N., Chevrette, T., \& Peretz, I. (2020). The impact of music training on inhibition control, phonological processing, and motor skills in kindergarteners: a randomized control trial. Early Child Development and Care. https://doi.org/10.1080/03004430.2020.1781841 
Brandt, A., Gebrian, M., \& Slevc, L. R. (2012). Music and early language acquisition. Frontiers in Psychology, 3, 327. https://doi.org/10.3389/fpsyg.2012.00327

Brewer, J. A. (2001). Introduction to early childhood education: Preschool through primary grades. Boston: Allyn \& Bacon.

Brown, E. D., Garnett, M. L., Velazquez-Martin, B. M., \& Mellor, T. J. (2017). The art of Head Start : Intensive arts integration associated with advantage in school readiness for economically disadvantaged children. Early Childhood Research Quarterly, 45, 204-214.

Caldwell, T. (1993). A Dalcroze perspective on skills for learning. Music Educators Journal, 79(7), 27. https://doi.org/10.2307/3398612

Campbell, P. S., \& Scott-Kassner, C. (2014). Music in childhood. New York: Schirmer.

Center on the Developing Child. (2016). Serve \& return interaction shapes brain circuitry. Retrieved February 2021, from https://developingchild.harvard.edu/ resources/serve-return-interaction-shapes-brain-circuitry/

Cross, A. F., \& Conn-Powers, M. (2014). Making the intentional decision to use an effective curriculum to promote children's learning. Early Childhood Education Journal, 42, 361-366. https://doi.org/10.1007/s10643-013-0623-4

Crow, N. (2017). The itsy bitsy spider: Sing along with me! Boston: Whispering Coyote Press.

Degé, F., \& Schwarzer, G. (2011). The effect of a music program on phonological awareness in preschoolers. Frontiers in Psychology, 2, 124.

Deli, E., Bakle, I., \& Zachopoulou, E. (2006). Implementing intervention movement programmes for kindergarten children. Journal of Early Childhood Research, $4(1), 5-18$.

Derri, V., Tsapakidou, A., Zachopoulou, E., \& Kioumourtzoglu, E. (2001). Effects of a music and movement programme on development of locomotor skills by children 4 to 6 years of age. European Journal of Physical Education., 6, 16-25.

Dodge, D. T. (2011). The creative curriculum for preschool [Kit]. Bethesda: Teaching Strategies.

Early years foundation stage statutory framework. (2017). Retrieved February 2021, from https://assets.publishing.service.gov.uk/government/ uploads/system/uploads/attachmentdata/file/596629/EYFS STATUTORY FRAMEWORK 2017.pdf

Early, D. M., Iruka, I. U., Ritchie, S., Barbarin, O. A., Winn, D.- M.C., Crawford, G. M., et al. (2010). How do pre-kindergarteners spend their time? Gender, ethnicity, and income as predictors of experiences in pre-kindergarten classrooms. Early Childhood Research Quarterly, 25(2), 177-193.

Edwards, L. C. (2013). Music and movement: A way of life for the young child. Pearson: Pearson University Press.

Ehrlin, A., \& Tivenius, O. (2018). Music in preschool class: A quantitative study of factors that determine the extent of music in daily work in Swedish preschool classes. International Journal of Music Education, 36(1), 17-33. https://doi. org/10.1177/0255761417689920 
Feierabend, J. (2004). The book of beginning circle games (First steps in music series).

Fuligni, A. S., Howes, C., Huang, Y., Hong, S. S., \& Lara-Cinisomo, S. (2012). Activity settings and daily routines in preschool classrooms: Diverse experiences in early learning settings for low-income children. Early Childhood Research Quarterly, 27(2), 198-209. https://doi.org/10.1016/j.ecresq.2011.10.001

Gillespie, C. W., \& Glider, K. R. (2010). Preschool teachers' use of music to scaffold children's learning and behaviour. Early Child Development and Care, 180(6), 799-808.

Greata, J. (2006). An introduction to music in early childhood education. Florence: Thomson Delmar Learning.

Golinkoff, R. M., Hirsh-Pasek, K., \& Singer, D. G. (2006). Why play = learning: A challenge for parents and educators. In D. G. Singer, R. M. Golinkoff, \& K. Hirsh-Pasek (Eds.), Play = Learning: How play motivates and enhances children's cognitive and social-emotional growth (pp. 3-12). Oxford: Oxford University Press.

Gooding, L., \& Standley, J. M. (2011). Musical development and learning characteristics of students: A compilation of key points from the research literature organized by age. Update Applications of Research in Music Education, 30(1), 32-45. https://doi.org/10.1177/8755123311418481

Hallam, S. (2010). The power of music: Its impact on the intellectual, social and personal development of children and young people. International Journal of Music Education, 28(3), 269-289.

Hargreaves, D. J., \& Zimmermann, M. P. (1992). Developmental theories of music learning. In R. Cowell (Ed.), Handbook of research on music teaching and learning (pp. 377-391). New York: Schirmer Books.

Head Start Child Development and Early Learning Framework. (2010). Retrieved February 2021, from https://www.giarts.org/sites/default/files/Head-StartChild-Development-Early-Learning-Framework.pdf

High Scope Educational Research Foundation. (2012). Retrieved February 2021, from https://highscope.org/wp-content/uploads/2018/03/COR-Advantage-toKDIs March-2018-SS.pdf

Hooper, P. G., \& Umansky, W. (2013). Young children with special needs. Pearson Higher Ed.

Hsieh, H. F., \& Shannon, S. E. (2005). Three approaches to qualitative content analysis. Qualitative Health Research, 15, 1277-1288.

Huriwitz, I., Wolff, P. H., Bortnick, B. D., \& Kokas, K. (1975). Nonmusical effects of the Kodaly music curriculum in primary grade children. Journal of Learning Disabilities, 8(3), 167.

Ilari, B. (2016). Music in the early years: Pathways into the social world. Research Studies in Music Education, 38(1), 23-39. International Society for Music Education [ISME]. (2016). Retrieved February 2021, from https://www.isme.org/ about 
Jaccard, J. L. (2014). Intonation begins in Kindergarten: The art and science of teaching music acoustically. Kodaly Envoy, 40(3), 60-67.

Jacobi, B. (2012). Kodály, literacy, and the brain: Preparing young music students to read pitch on the staff. General Music Today, 25(2), 11-18. https://doi. org/10.1177/1048371311414182

Jacobi, B. (2012). Strategies for integrating Kodály principles into music literacy instruction. Kodaly Envoy, 38(3), 28-31. Jones, E. (2012). The emergence of emergent curriculum. Young Children, 67, 66-68.

Jones, E., \& Nimmo, J. (1994). Emergent curriculum. Washington, DC: NAEYC.

Jordan-DeCarbo, J., \& Galliford, J. (2011). The effect of an age-appropriate music curriculum on motor and linguistic and nonlinguistic skills of children three to five years of age. In S. L. Burton \& C. C. Taggart (Eds.), Learning from young children (pp. 215-230). Lanham: Rowman \& Littlefield Education.

Kirsten, J. (2006). Pre-kindergarten music education standards and the Opportunity-to-learn standards as applied to preschool settings in the United States. Doctoral dissertation. University of Miami.

Kirschner, S., \& Tomasello, M. (2009). Joint drumming: Social context facilitates synchronization in preschool children. Journal of Experimental Child Psychology, 102(3), 229-314.

Kostelnik, M. J., Soderman, A. K., Whiren, A., \& Rupiper, M. L. (2019). Developmentally appropriate curriculum: Best practices in early childhood (7th ed.). Pearson: Pearson University Press.

Kretchmer, D. (2002). Developing pre-service teacher self-efficacy to integrate music in elementary classrooms : An investigation in growth through participation, observation and reflection. Unpublished doctoral dissertation. University of Colorado.

Ladd, G. W., Birch, S. H., \& Buhs, E. S. (1999). Children's social and scholastic lives in kindergarten: Related spheres of influence? Child Development, 70, 1373-1400.

Lee, Y. (2009). Music practices and teachers' needs for teaching music in public preschools of South Korea. International Journal of Music Education, 27(4), 356-371. https://doi.org/10.1177/0255761409344663

Lenzo, T. B. (2014). Online professional development in preschool settings: Music education training for early childhood generalists. Doctoral dissertation, Kent State University.

Lonigan, C. J., \& Shanahan, T. (2008). Developing early literacy: Report of the national early literacy panel. Retrieved February 2021, from https://files.eric. ed.gov/fulltext/ED508381.pdf

Lorenzo, O., Herrera, L., Hernández-Candelas, M., \& Badea, M. (2014). Influence of music training on language development. A longitudinal study. Procedia - Social and Behavioral Sciences, 128, 527-530. https://doi.org/10.1016/j. sbspro.2014.03.200 
Marsh, K., \& Young, S. (2006). Musical play. In G. E. McPherson (Ed.), The child as musician: A handbook of musical development (pp. 289-310). New York: Oxford University Press.

May, B. N., Willie, K., Worthen, C., \& Pehrson, A. (2017). An analysis of state music education certification and licensure practices in the United States. Journal of Music Teacher Education, 27(1), 65-88. https://doi. org/10.1177/1057083717699650

Mead, V. H. (1996). More than mere movement. Music Educators Journal, 82(4), 38. https://doi.org/10.2307/3398915

Merrion, M. (Ed.). (1989). What works: Instructional strategies for music education. Reston: MENC.

Meyers, B. (2017). Imagining the Kodály-centered instrumental classroom. Kodaly Envoy, 43(3), 18-19.

Michè, M. (2002). Weaving music into young minds. Albany, NY: Delmar Thomson Learning.

Ministry of Education, Culture, Sports, Science and Technology. (2008). Retrieved February 2021, from http://www.mext.go.jp/component/english/ icsFiles/ afieldfile/2011/04/07/1303755 002.pdf

Mizener, C. P. (2008). Enhancing language skills through music. General Music Today, 21(2), 11-17. https://doi.org/10.1177/1048371308316414

NAEYC Early Learning Standards and Accreditation Criteria \& Guidance for Assessment. (2017). Retrieved July 2017, from https://www.naeyc.org/sites/ default/files/globally-shared/downloads/PDFs/accreditation/early-learning/ Standards\%20and\%20Accreditation\%20Criteria\%20\%26\%20Guidance\%20 for\%20Assessment April\%202017 3.pdf

Nardo, R. L., Custodero, L. A., Persellin, D. C., \& Brink Fox, D. (2006). Looking back, looking forward: A report on early childhood music education in accredited American preschools. Journal of Research in Music Education, 54(4), 278-292.

National Association for Music Education [NAfME]. (2014). Retrieved February 2021, from https://nafme.org/wp-content/uploads/2014/11/2014-MusicStandards-PK-8-Strand.pdf

National Association for the Education of Young Children. (2009). NAEYC position statement: Developmentally appropriate practice in early childhood programs serving children from birth through age 8. Retrieved February 2021, from https://www.naeyc.org/sites/default/files/globally-shared/downloads/PDFs/ resources/positionstatements/PSDAP.pdf

National Curricular Common Base in Brazil. (2017). Retrieved February 2021, from http://basenacionalcomum.mec.gov.br/

Nebraska Early Learning Guidelines for Ages 3 to 5. (2018). Retrieved February 2021, from https://cdn.education.ne.gov/wp-content/uploads/2018/06/ELGPDF.pdf

Nicolopoulou, A. (2010). The alarming disappearance of play from early childhood education. Human Development, 53, 1-4. https://doi.org/10.1159/000268135 
Perlmutter, A. (2009). General music. Teaching Music, 16(5), 48.

Pica, R. (2012). Experiences in movement and music. Boston: Cengage Learning.

Raffi. (1997). Baby beluga. New York: Crown Publishers.

Rajan, R. S. (2017). Preschool teachers' use of music in the classroom: A survey of park district preschool programs. Journal of Music Teacher Education, 27(1), 89-102.

Reynolds, A. M., \& Burton, S. L. (2017). Serve and return: Communication foundations for early childhood music policy stakeholders. Arts Educational Policy Review, 118, 140-153. https://doi.org/10.1080/10632913.2016.1244779

Runfola, M., Etopio, E., Hamlen, K., \& Rosendal, M. (2012). Effect of music instruction on preschoolers' music achievement and emergent literacy achievement. Bulletin of the Council for Research in Music Education., 192, 7-27.

Sarrazin, N. (2016). Music and the child. Open SUNY Textbooks. Retrieved February 2021, from https://milnepublishing.geneseo.edu/music-and-the-child/

Schachter, R. E., Piasta, S., \& Justice, L. (2020). An investigation into the curricula (type and quality) used by early childhood educators. NHSA Dialog, 23(2), 21-50.

Sendak, M., \& Schickele, P. (1963). Where the wild things are. Danbury: Weston Woods.

Shamrock, M. (1997). Orff-Schulwerk: An integrated foundation. Music Educators Journal, 83(6), 41. https://doi.org/10.2307/3399024

South African National Curriculum Framework. (2015). Retrieved February 2021, from https://www.unicef.org/southafrica/media/911/file/SAF-nationalcurriculum-framework-0-4-En.pdf

Strong, A. (2012). A perspective on preschool \& Kindergarten: Interview with Katalin Forrai. Kodaly Envoy, 38(2), 4-9.

Suthers, L., \& Niland, A. (2007). An exploration of young children's engagement with music experiences. In K. Smithrim \& R. Uptis (Eds.), Listen to their voices: Research and practice in early childhood music (pp. 19-32). Toronto: Canadian Music Educators' Association.

Trainor, L. J., \& Cirelli, L. K. (2015). Rhythm and interpersonal synchrony in early social development. Annals of the New York Academy of Sciences, 1337, 45-52.

Valerio, W. H., Reynolds, A. M., Bolton, B. M., Taggart, C. C., \& Gordon, E. E. (1998). Music play: The early childhood music curriculum guide for parents, teachers, and caregivers. GIA.

Winsler, A., Ducenne, L., \& Koury, A. (2011). Singing one's way to selfregulation: The role of early music and movement curricula and private speech. Early Education and Development, 22, 274-304. https://doi. org/10.1080/10409280903585739

Wood, E. (2004). Developing a pedagogy of play. In A. Anning, J. Cullen, \& M. Fleer (Eds.), Early childhood education: society and culture (pp. 19-30). Thousand Oaks: SAGE Publications Ltd. 
Young, S. (2009). Music 3-5. Milton Park: Routledge.

Young, S., \& Ilari, B. (2018). Musical participation from birth to three: Towards a global perspective. In G. McPherson \& G. Welch (Eds.), Oxford Handbook of music education (Vol. 2, pp. 279-295). Oxford: Oxford University Press.

Zachopoulou, E., Derri, V., Chatzopoulou, D., \& Ellinoudis, T. (2003). Application of Orff and Dalcroze activities in preschool children: Do they affect the level of rhythmic ability? Physical Educator, 60(2), 51. . 


\section{Online Appendix: More information about music curricula Music Curricula Alignment ${ }^{1}$}

\section{Kindermusik@School's Laugh \& Learn \\ Background Company Information. Kindermusik@ School is designed for use in child-} care centers, preschools, and private at-home child-care programs. They market the curricula as "music time in a box" (www.kindermusik.com). Kindermusik@School provides Teach-Along CDs that have a narrated voice giving instructions to the children and teachers, detailed online lesson plans, instruments, visual aids, and monthly home materials for children to share with their families. Kindermusik@ School also has online resources like e-books, videos, games and activities, and additional music. Kindermusik@ School also offers optional professional development for the preschool teacher, either in-person or online. This professional development helps teachers incorporate music into the entire school day, and aids teachers in gaining classroom management skills (www.kindermusik.com).

Laugh \& Learn Curriculum. The Laugh \& Learn curriculum is designed for the preschool classroom and aims to be flexible so music time can either last 10, 15, 20 or 30 minutes. Each lesson plan includes focused listening, vocal play, movement, and instrument play, with opportunities for all of them depending on the length of music time. The creators state it aligns with Common Core State Standards, Head Start and Early Head Start Standards and Frameworks, the Early Childhood Environmental Rating Scale, and the Classroom Assessment Scoring System Pillars (www.kindermusik.com). Because of the narrated CD, preschool teachers do not need to be particularly musical; the CD narrator tells the students what to do and sings all the songs. The preschool teacher is there to be a model and to facilitate but does not need to be able to, for example, find starting pitches for songs or read musical notation. One limitation of

\footnotetext{
${ }^{1}$ The curricula reviewed were all gathered in 2017. Updates may have occurred that are not reflected in this review.
} 
the Laugh \& Learn curriculum is that an adult male sings some of the songs on the model CD, an octave below where the children should be singing. Campbell and Scott-Kassner (2014), teach that children cannot sing an octave above what they hear until the fourth grade. Unless the preschool teacher knows how or to sing an octave above what they hear on the CD, the children are presumably not going to be singing in tune with a male vocalist. As seen in Table 1, this curriculum covers all the Best Practice standards except for some of the songs being pitched too low because an adult male is singing an octave too low.

Table 1

Kindermusik@SchoolLaugh and Learn Alignment

\section{Best Practice Standards Laugh \& Learn}

1. Instruction and materials for singing are provide to and with children often Yes - singing is part of every lesson, though most of the singing is with children and not to children

2. Songs provided are pitched in the correct range for children, middle $\mathrm{C}$ to $\mathrm{A}$ above middle $\mathrm{C}$ Yes-but adult males sing some of the songs on the $\mathrm{CD}$, which is not in the correct range for preschool children

\begin{tabular}{ll}
\hline $\begin{array}{l}\text { 3. Songs and activities reflect cultural } \\
\text { diversity }\end{array}$ & Yes-songs are from varied cultures \\
\hline $\begin{array}{l}\text { 4. Songs and activities allow children to } \\
\text { explore and experience a variety of music }\end{array}$ & $\begin{array}{l}\text { Yes-children are exposed to a variety of } \\
\text { distinctive styles of music }\end{array}$ \\
\hline $\begin{array}{l}\text { 5. Instruction and materials give children } \\
\text { opportunities to experiment with a variety of } \\
\text { instruments }\end{array}$ & Yes-instrument play is part of every lesson \\
\hline $\begin{array}{l}\text { 6. Instruction and materials give children } \\
\text { opportunities to dance and move to music }\end{array}$ & $\begin{array}{l}\text { Yes-movement and dancing are part of } \\
\text { every lesson plan }\end{array}$ \\
\hline $\begin{array}{l}\text { 7. Children are provided many and varied } \\
\text { open-ended opportunities and materials to } \\
\text { express themselves creatively through music } \\
\text { and dance }\end{array}$ & $\begin{array}{l}\text { Yes-Kindermusik includes instruments in } \\
\text { the cost of the curriculum. Many activities are } \\
\text { free play, where the child can play their }\end{array}$ \\
$\begin{array}{ll}\text { instrument or move freely around the room } \\
\text { performance-based }\end{array}$ & $\begin{array}{l}\text { Yes-this curriculum is based on } \\
\text { participatory activities and not on memorizing } \\
\text { songs for performance }\end{array}$ \\
\hline $\begin{array}{l}\text { 9. Instruction and activities give children } \\
\text { opportunities to discriminate and describe } \\
\text { musical qualities using vocabulary and } \\
\text { personal preference }\end{array}$ & $\begin{array}{l}\text { Yes-each lesson includes focused listening } \\
\text { that has children discriminating between } \\
\text { instruments }\end{array}$ \\
\hline
\end{tabular}




\section{The Musical Child's Sing and Play 1}

Company Background Information. The Musical Child has created music curricula for use in child-care centers, preschools and at home. Sing and Play is designed for children ages three to five. The entire curriculum materials are available for purchase online including audio for all the songs with and without vocal accompaniment and the educator's book (Biddiss, 2008). The educator's book contains information about the program, equipment set up, lesson overview, and lesson plans, instructions, and a simple music score. Each activity and song have an added "Why?" section that includes rationales as to why this activity is essential and how it is adding to the child's musical and non-musical growth (Biddiss, 2008). The teacher is responsible for obtaining the musical instruments as opposed to the Kindermusik curriculum that includes the musical instruments.

Sing and Play 1 Curriculum. There are two curricula for one preschool year, Sing and Play 1 and Sing and Play 2; Sing and Play 1 will be reviewed in this document. Each curriculum has five themes that include sets of songs and ten activities. Sample themes are farming, cooking, the sea, and holiday fun. Each day during music time, the children complete ten activities with the songs.

1) Social conventions - greeting song, put away the instruments song and farewell song

2) Body percussion — work on internalizing a steady beat using the body as an instrument

3) Fingers-Fingerplay songs that teach fine motor skills

4) Memory — these songs help children memorize sequences like numbers, days of the week, and the alphabet 
5) Rhythm instruments - play and exploration with unpitched rhythm instruments like drums and shakers

6) Melody and harmony instruments - play and explore on pitched instruments like chime bars

7) Drama and movement—creating actions and stories with the music

8) Games and dances—-social movement activities and circle dances

9) Music appreciation—-listening to music from diverse cultures

10) Story songs with visual media—a resting activity to calm children, stories that are sung with a book

Like the Laugh and Learn curriculum, Sing and Play 1, covers all the Best Practice standards, except that many of the songs are pitched for the adults singing them, and many adult males are singing on the reference CDs (see Table 2). In the Kindermusik curriculum, if children are singing an octave above the male vocal model, the children are singing in the correct range. In the Laugh and Learn curriculum, even if children are singing an octave above the male vocal model, they will still be singing notes that are too low for their registers. Most children are not able to accurately sing in tune lower than a $\mathrm{D}$ above middle $\mathrm{C}$, and the children are not able to sing an octave higher than the model they are given until fourth grade.

Table 2

Sing and Play 1 Alignment

\begin{tabular}{ll}
\hline \multicolumn{1}{c}{ Best Practice Standards } & \multicolumn{1}{c}{ Sing and Play 1 } \\
\hline $\begin{array}{l}\text { 1. Instruction and materials for singing are } \\
\text { provide to and with children often }\end{array}$ & $\begin{array}{l}\text { Yes-over 170 songs are included in the } \\
\text { curriculum with CDs to accompany them. }\end{array}$ \\
\hline $\begin{array}{l}\text { 2. Songs provided are pitched in the correct } \\
\text { range for children, middle C to A above }\end{array}$ & $\begin{array}{l}\text { No-most of the songs are in the right key } \\
\text { but have notes that are too low for young } \\
\text { middle C }\end{array}$ \\
$\begin{array}{l}\text { children. Also, an adult male sings an octave } \\
\text { below where the children should sing on } \\
\text { some of the songs on the CD }\end{array}$ \\
\hline
\end{tabular}




\begin{tabular}{ll}
\hline $\begin{array}{l}\text { 3. Songs and activities reflect cultural } \\
\text { diversity }\end{array}$ & $\begin{array}{l}\text { Yes-the songs are based on traditional } \\
\text { melodies that are found in many cultures }\end{array}$ \\
\hline $\begin{array}{l}\text { 4. Songs and activities allow children to } \\
\text { explore and experience a variety of music }\end{array}$ & $\begin{array}{l}\text { Yes-there are about 170 songs included in } \\
\text { the 36-week curriculum }\end{array}$ \\
\hline $\begin{array}{l}\text { 5. Instruction and materials give children } \\
\text { opportunities to experiment with a variety of } \\
\text { instruments }\end{array}$ & $\begin{array}{l}\text { Yes-ten developmental activities are } \\
\text { included in a thematic group of songs. One of } \\
\text { the activities is "Rhythm Instruments, } \\
\text { Melody, and Harmony Instruments." }\end{array}$ \\
\hline $\begin{array}{l}\text { 6. Instruction and materials give children } \\
\text { opportunities to dance and move to music }\end{array}$ & $\begin{array}{l}\text { Yes-ten developmental activities are } \\
\text { included in a thematic group of songs. One of } \\
\text { the activities is "Games and Dances." }\end{array}$ \\
\hline $\begin{array}{l}\text { 7. Children are provided many and varied } \\
\text { open-ended opportunities and materials to } \\
\text { express themselves creatively through music } \\
\text { and dance }\end{array}$ & $\begin{array}{l}\text { Yes-during certain songs, children are } \\
\text { invited to explore and play pitched } \\
\text { instruments and not necessarily encouraged to } \\
\text { play the right note at the right time. }\end{array}$ \\
$\begin{array}{l}\text { 8. Music is participatory instead of } \\
\text { performance-based }\end{array}$ & $\begin{array}{l}\text { Yes-this curriculum is based on } \\
\text { participatory activities and not on memorizing } \\
\text { songs for performance. }\end{array}$ \\
\hline $\begin{array}{l}\text { 9. Instruction and activities give children } \\
\text { opportunities to discriminate and describe } \\
\text { musical qualities using vocabulary and } \\
\text { personal preference }\end{array}$ & $\begin{array}{l}\text { Yes-ten developmental activities are } \\
\text { included in a thematic group of songs. One of } \\
\text { the activities is "Musical Appreciation }\end{array}$ \\
& Suggestions." \\
\hline
\end{tabular}

\section{Do Re Me and Maria's World Music and Rhythm Talk}

Company Background Information. Do Re Me and Maria is a children's music company that produces early childhood music curricula and music recordings. From the website (www.doremeandmaria.com), teachers and parents can download curricula, audio recordings, and supplemental lesson plans.

World Music and Rhythm Talk Curriculum. World Music and Rhythm Talk is a 36-week comprehensive music program for children ages 3-7. The kit comes with the following:

- Complete curriculum guide including objectives and knowledge standards; 
- Five music CDs featuring professionally recorded songs. The CDs also contain tracks that introduce songs and different activities, giving children vocabulary and introducing words from various languages;

- DVD with video tutorials for the preschool teacher;

- Songbook with all the songs for easy access;

- Five more CDs with classical music recordings and active listening and role-play activities;

- Book about the orchestra;

- Flashcards of instruments of the orchestra;

- Picture cards of favorite food (for use in some of the activities) and;

- Stuffed animal containing a recording device for the teacher to record new words (usually in a foreign language) that will be used while learning a new song. When the child hugs the stuffed animal, the teacher recording is activated, and the child hears the new phrase (Alley, 2006).

The strength of World Music and Rhythm Talk is its focus on international music and games. The sample lessons I received included a bear hunt game from Poland and a raspberry-picking dance from Russia. Two limitations stand out for World Music and Rhythm Talk. First, the author claims the lessons are suitable for children ages three to seven, but in the lessons reviewed, the material seemed geared toward older children. Activities included learning many words in foreign languages, children in a group playing different instruments on a cue from the teacher, and marching to a beat and playing a drum at the same time, which most preschoolers (or even adults) cannot do. It is not always apparent from the lesson plans what activities are appropriate for each age group. It would be helpful to have a base lesson for preschoolers and then labeled 
extension activities for Kindergarten and First-grade students. Like the two previous curricula, the songs were pitched too low for preschool children. Moreover, the songs were too musically complex for preschool children. Most preschool music textbook authors suggest using short, simple, songs that use repetition (Campbell \& Scott-Kassner, 2014; Pica, 2012; Miché, 2002) and World Music and Rhythm Talk does not use this.

Table 3

World Music and Rhythm Talk Alignment

Best Practice Standards

1. Instruction and materials for singing are provide to and with children often

2. Songs provided are pitched in the correct range for children, middle $\mathrm{C}$ to $\mathrm{A}$ above middle $\mathrm{C}$

3. Songs and activities reflect cultural diversity

4. Songs and activities allow children to explore and experience a variety of music

5. Instruction and materials give children opportunities to experiment with a variety of instruments

6. Instruction and materials give children opportunities to dance and move to music

7. Children are provided many and varied open-ended opportunities and materials to express themselves creatively through music and dance
World Music and Rhythm Talk

Yes-Each lesson includes singing multiple songs

No- only a few songs were given to sample, but many of them were pitched for the comfort of the singer, and not for small children. They were also musically complex. Yes - this is the most prominent strength of this curriculum. Songs and games are from all over the world.

Yes - the sample songs provided came from all over the world Yes - though it might be difficult for preschool teachers to obtain all the instruments requested for this curriculum (like güiros and agogo bells)

Yes-but there was only one- the activity taught children to march to a beat, but the children were to be seated and march their feet from a seated position.

Yes-this curriculum has many opportunities for children to act out musical stories dramatically.
8. Music is participatory instead of performance-based

9. Instruction and activities give children opportunities to discriminate and describe musical qualities using vocabulary and personal preference
Yes - this curriculum is based on participatory activities and not on memorizing songs for performance.

No- the sample lesson materials provided no apparent discrimination activities 


\section{Preschool Prodigies PSP Playground}

Company Background. Preschool Prodigies is based on the idea that children's musical ability will increase if children have meaningful interaction with pitch during their auditory critical period (Young, N.D.). Rob Young, the creator of Preschool Prodigies and a music and movement teacher, explored the Taneda method, which teaches children between the ages of three to five to have absolute pitch through a highly structured sequence of ball games and piano drills (wehearandplay.com). Young also studied the work of Diana Deutsch who studies tone languages and how learning a tone language like Chinese increases the likelihood of developing absolute pitch, meaning the ability to identify and reproduce a note without an external reference like a piano (Deutsch, 2002). Young set out to create a music program that gave children more exposure and interaction with pitch, to simulate the exposure children, who learn tone languages, experience.

PSP Playground Curriculum. Young created PSP Playground for use in preschool classrooms. The curriculum consists of colorful and bright videos, narrated by creator Rob Young; each video introduces a musical concept like a specific musical note, a rhythm, or a song. Colorful desk bells, purchased separately through the Preschool Prodigies website, are the musical instruments used in this curriculum, and children play the bells while singing along to the videos. The videos are meant to be the stand-in for an in-class music specialist, with no additional training needed from the generalist teacher. The videos should be repeated two to three times before moving on to the next video in the series.

A strength for PSP Playground is the quality of the videos. Each video has quality graphics, sound, and is engaging to the viewer. The major weakness of the curriculum is Rob Young voices all the videos and sings an octave below where the children should sing. As has 
been discussed previously, children need a vocal model that sings in the same range as the children.

Table 4

PSP Playground Alignment

\section{Best Practice Standards}

1. Instruction and materials for singing are provide to and with children often 2. Songs provided are pitched in the correct range for children, middle $\mathrm{C}$ to $\mathrm{A}$ above middle $\mathrm{C}$

\section{PSP Playground}

Yes-most instruction centers on children singing

No-In the first lesson, the instructor introduces the note middle $\mathrm{C}$ and has the children sing along with him. Middle $\mathrm{C}$ is low for preschool children, and he then sings an octave below Middle $\mathrm{C}$, moving even further away from a preschool child's vocal range. $\mathrm{He}$ also has them experiment with singing the note $\mathrm{C}$ in different octaves; preschool children are unable to do this. In all the sample lessons reviewed, he sings in the incorrect range for preschool children.

3. Songs and activities reflect cultural diversity

No-most songs are western folk songs like Mary Had a Little Lamb, Row Row Row Your Boat, and Ba Ba Black Sheep

4. Songs and activities allow children to explore and experience a variety of music

5. Instruction and materials give children opportunities to experiment with a variety of instruments

6. Instruction and materials give children opportunities to dance and move to music 7. Children are provided many and varied open-ended opportunities and materials to express themselves creatively through music and dance

\begin{tabular}{ll}
\hline $\begin{array}{l}\text { 8. Music is participatory instead of } \\
\text { performance-based }\end{array}$ & $\begin{array}{l}\text { Yes-there is no performance component to } \\
\text { the curriculum }\end{array}$ \\
\hline $\begin{array}{l}\text { 9. Instruction and activities give children } \\
\text { opportunities to discriminate and describe } \\
\text { musical qualities using vocabulary and }\end{array}$ & $\begin{array}{l}\text { No-the sample curriculum included a video } \\
\text { where children heard a song, and then Mr. } \\
\text { personal preference }\end{array}$ \\
$\begin{array}{l}\text { Rob asked them to identify the song, but not } \\
\text { the qualities of the music like loud and soft. }\end{array}$
\end{tabular}

No-most songs are western folk songs like Mary Had a Little Lamb, Row Row Row Your Boat, and Ba Ba Black Sheep No- this curriculum only uses colored desk bells

No--besides keeping a beat by tapping legs, this curriculum is not movement based No - the videos are highly structured using a call and response format 


\section{The Tuneables I Love Music!}

Company Background. The Tuneables is a preschool music curriculum created by Drs. Robert and Patsy Johnson, under the company umbrella, Music Intelligence Project. The Music Intelligence Project's goal was to break down two barriers they experienced during preschool music education; the first is the ability of the preschool teacher to model correct musical performance like pitch and rhythm. The second barrier is curriculum and knowing what to teach and when (J. Todd, Personal Communication, August 7, 2017). Dr. Patsy Johnson was a preschool teacher before earning her Ed.D. and was faculty in Educational Leadership departments (www.musicintelligenceproject.com). Dr. Robert Johnson taught music in the public schools and received his Ph.D. in Music. During his time as a professor, he trained pre-service teachers and composed or arranged over two hundred songs appropriate for young children's voices (www.musicintelligenceproject.com).

I Love Music! Curriculum. The Tuneables: I Love Music! Curriculum is based on a 30minute animated video. In the video, two young children arrive in Tuneville at the music shop for their very first music lesson. They are introduced to characters who help them learn how to sing, keep and move to a beat, discriminate between music events that are the same or different and name musical and rhythmic patterns. During this 30-minute video, all the songs included in the curriculum are introduced along with all of the musical and rhythmic elements children will learn (Johnson \& Johnson, 2011). The preschool teacher has the children watch this 30-minute video a few times and then start providing the musical instruction using the songs and activities demonstrated in the video and on additional CDs. For each of the songs, the teacher's manual provides:

- The key of the song and the tempo; 
- The action the child and teacher should take during the song;

- The learning objective;

- Strategies for the teacher;

- Signs of success, describing the target behavior for the children and;

- Enrichment—ways to extend the learning during subsequent repetitions.

Also included in the teacher's manual is instruction for teaching music correctly to young children, sheet music for all the songs and two lesson plan templates. This curriculum is the only one reviewed that does not provide lesson plans, but instead provides all the music and activities and gives instructions on how to create a lesson plan. This lack of structure could be intimidating to a preschool teacher with little musical experience.

The website and teachers' manual both claim the curriculum is "based on years of research and proven practice experience" (www.musicintelligenceproject.com/projects) and "has been applied and refined over a numbers [sic] of years with thousands of children in hundreds of classes" (Johnson \& Johnson, 2011 p. 51). It is unclear if the I Love Music curriculum has been applied in a preschool classroom, or just the components Drs. Johnson created have been applied and refined in a preschool classroom, and the curriculum is the culmination of that experience. Table 5

I Love Music! Alignment

Best Practice Standards

1. Instruction and materials for singing are provide to and with children often

2. Songs provided are pitched in the correct range for children, middle $\mathrm{C}$ to $\mathrm{A}$ above middle $\mathrm{C}$

3. Songs and activities reflect cultural diversity
I Love Music!

Yes-most of the instruction has children sing

Yes - this is the only curriculum reviewed in this document where all the songs the children sing are pitched correctly and have a vocal model singing in the correct range No-most songs in this curriculum are original to the curriculum and are simple two or three note songs that do not reflect a range 
of cultures. Also, while the children shown on the videos are culturally diverse, the animated characters are Caucasian

4. Songs and activities allow children to explore and experience a variety of music
Yes-with reservations, the curriculum includes 18 singing songs, plus 9 more rhythms, listening and movement songs. However, the music that is not original to the curriculum is from the Western Classical tradition like Mozart's Eine Kleine Nacht Musik and Haydn's Surprise Symphony, or folk songs like This Old Man and Love Somebody. These songs come from Western folk traditions and do not reflect cultural diversity
5. Instruction and materials give children opportunities to experiment with a variety of instruments

No - the recommended musical instruments are a keyboard, one small hand drum and one set of resonator bells and bell ladder. These instruments are for the teacher only to provide an accurate pitch for the children's voices and an accurate beat pattern for the children to replicate

6. Instruction and materials give children Yes-most of the movement focuses on learning to move to the beat of the song opportunities to dance and move to music 7. Children are provided many and varied open-ended opportunities and materials to express themselves creatively through music and dance No- the curriculum is very structured. The teacher could provide these opportunities, but the lesson plan templates do not encourage open-ended musical expression
Yes-but there is a sample music performance script at the end of teachers' manual to use for an end of year production if wanted

9. Instruction and activities give children opportunities to discriminate and describe musical qualities using vocabulary and personal preference first hear the music, then perform the music,
Yes - the curriculum is structured, so children and finally, label the music. The children name tonal syllables (Do Re Mi) and rhythm chanting. There is no direct instruction given to teachers to discuss personal preference with children 


\section{References}

Alley, M. (2006). World Music and Rhythm Talk-Educator's Manual.

Biddiss, C. (2008). Sing and Play 1 Singing All Day Long-Educator's Book.

Campbell, P. S., \& Scott-Kassner, C. (2014). Music in Childhood. Boston, MA: Schirmer.

Deutsch, D. (2002). The puzzle of absolute pitch. Current Directions in Psychological Science, 6, 200-204.

Miché, M. (2002). Weaving music into young minds. Albany, NY: Delmar Thomson Learning.

Pica, R. (2012). Experiences in movement and music. Belmont, CA: Wadsworth, Cengage Learning.

Young, M. (n.d.) retrieved from http://www.preschoolprodigies.com/wpcontent/uploads/2017/05/Prodigies-Playground-Scope-and-Sequence-web.pdf) 